\title{
Analysis of Effective Factors on Presence of Citizens in Urban Spaces, Case Study: Towhid Square in Tehran
}

\author{
Amin Khakpour ${ }^{1}$, Sadegh Sabouri ${ }^{1} \&$ Minoo Harirchian ${ }^{2}$ \\ ${ }^{1}$ School of Urban and Regional Planning, College of Fine Arts, University of Tehran, Tehran, Iran \\ ${ }^{2}$ School of Urban Design, College of Fine Arts, University of Tehran, Tehran, Iran \\ Correspondence: Amin Khakpour, School of Urban and Regional Planning, College of Fine Arts, University of \\ Tehran, Tehran, Iran. Tel: 98-91-2018-7394. E-mail: aminkhakpour@alumni.ut.ac.ir
}

Received: December 9, 2016

doi:10.5539/jsd.v10n3p35

\author{
Accepted: March 9, 2017 \\ Online Published: May 31, 2017 \\ URL: https://doi.org/10.5539/jsd.v10n3p35
}

\begin{abstract}
This study attempts to respond the question that "which factors and indices are effective on citizen's presence in urban spaces?" This is important because by identifying and analyzing this factors and indices, it could be possible to improve weaknesses and promoting strengths of each urban spaces. In Towhid Square, the inadequate space for citizens and the dominance of car traffic over pedestrians are some of the most reasons of lack of presence of citizens in the square as an urban space. The study is analytic and the data is collected from library and fieldwork. Cochran's formula is applied to determine sample size which is 149. In the next step, by reviewing literature, indices were extracted. After providing questionnaire based on indices and by Likert Scale, we applied it to the case study and completed the survey. In data analysis, SPSS ${ }^{\circledR} 17$ software is used and in the final step of analyses, four factors are achieved. The results of the study show, despite the hypotheses, the most important factor of non-presence (in contrast with passing) of citizens in Towhid square is "management" factor which is leading to the creation of other inhibiting elements of citizen's presence in urban space.
\end{abstract}

Keywords: factor analysis, management factor, presence of citizens, Towhid square, urban space

\section{Introduction}

In Iran in the past, the square was any wide and extensive location. In addition, the square is referred to a big and open space in which livestock, vegetable; fruit, coal, and stray were sold. These squares were commercial ones and until now, such places are called square, as "fruit and Vegetable Square". Other type of squares were governmental squares in which governmental institutes were located as Arg square of Tehran or Naghsh-e Jahan square in Isfahan, military square used for military training, military activities, etc. like Toupkhane square. Also the main square of the city was the main gathering location of people. These main squares consisted of various public buildings or spaces such as mosque, bazar, great city reservoir and so forth like the Sabze Meydan (Sabze square) of Tehran or Sabze Meydan of Qazvin.

Square was the first public domain constructed by human-beings to use as an urban space. Square was created for the first time in the western urban planning by collection of houses around an open space and in front of the temples (Karier, 1996). In Iran's urban planning, the square in front of the temple was small and common people were not allowed to participate in religious rituals. Only rich people could have a part in Pars and Mad cities (Khoshnevis, 2006).

The success of urban spaces is consistent with the use of space and presence of human being. Indeed, architecture and urban planning instead of separation should increase social interactions and unity of people. But nowadays in urban spaces, we are encountered with reduction of social participation and relations of residents (Behzadfar, 2013). Over history, urban spaces play an important role in the socio-economic life of residents and act as the center of changes in cities. Therefor we can say that in the modern era, with deep changes in all aspects of life and residence, the majority of urban spaces are turned into problematic places (Soltani, 2011).

Dull, unqualified, non-human and insignificant urban spaces are the features of today's cities. In other words, unsuitable development and weakening of place sense and its attachment have led to alteration of citizens' image of place. In most cases, the changes in physical environment, land uses and activities eliminate the meanings and values of squars (Sajadzade, 2013). In past, what really defined a square was the active presence of citizens and 
their plays in citizenships role.

To sum up, we can say that in most Iran's cities, due to the change of dynamic an active urban spaces which is provided with the dominance of the pedestrian movement and their presence to the spaces considering only the rider needs and moreover all social interactions are destroyed, we cannot call the name of square to them anymore. Hence in this study, based on Towhid square as our case study, we attempt to respond the question related to this issue; Which factors are effective in the presence of citizens in urban spaces?

\subsection{Describe Relevant Scholarship}

In the history of human civilization, the square is the most influential urban space for social interactions and many citizens of new and historical cities recognize urban areas by squares (Khoshnevis, 2006). Open public spaces can provide motivation and free selection of behaviors, movements and next explorations for significant numbers of people and citizens (Lynch, 1972). In other words, square is a regular space, which adapts itself to a variety of behaviors and provides inspiring ground for self-motivated actions (Ibid).

In public spaces, there is an opportunity to break the new social borders. Moreover, unformulated interactions occur and people are mixed in a new social environment (Ibid). Thus, the basic condition for considering a public space as urban space is that social interaction occurs and consequently, we can say that those soft and hard spaces that are not as the ground of social interactions cannot be called urban spaces (Pakzad, 2010).

Collective life is an opportunity to release of routine tensions, leisure time, social interactions and gathering of various groups, for participation, freedom of opinion and its expression in space. Collective life in public open spaces depends upon promoting social interactions (Sennette,1974), absorbing different people and groups (Whyte,1980), social security and motivating to increase of tolerating various groups in space, high sociability (Marcus\&Francis, 1998) and creating live and active space (Behzadfar, 2013). Some of the theorists considering urban space from social-cultural relations are Amos Rapoport, Louis Mumford, Kevin Lynch, Rob Karrier, Manuel Castells, and Paul Zucker.

According to Madanipour, public spaces are those in which strangers participate; The people who are not our relatives, friends or co-workers. These spaces are the field for politics, religion, trade, sport and a space for peaceful living and non-personal behaviors (Madanipour, 2008). Oldenburg considers urban spaces as third place, the space beside the house and workplace, the space for voluntarily gathering of people (Oldenburg, 1999). Jurgen Habermas considers public spaces the one in which people gather for participation in open discussion (Holab, 2010).

The Website "pps.org" by evaluation of more than 2000 public spaces over the world has found that a public space with four components: Access \& Linkage, Comfort \& Image, Uses \& Activities and Sociability is a successful public space in terms of urban planning.

Urban spaces are beyond the places that are used merely for recreation. According to Goodman, these places are vital elements in our environment and with positive and necessary functions, provide some opportunities for recreation of people. They also protect the natural resources and affect the great spectrum of decisions of economic development (Goodman, 1968).

Cullen pointed out that in order to enjoy moving in the city and watching, it is better to give priority to the sidewalk and its continuity prepare the city for pedestrian movement. He believed that rider arteries eliminate the individual identity and by creating a logical network of pedestrian paths, human pattern can be created (Cullen, 1961).

Another notable viewpoint about squares and public spaces belongs to Gehl. He is against full separation of pedestrians and riders. However, he describes the city with slow traffic as a livable city in which many people spent more time in public spaces. In addition, the probability of citizens' presence in spaces between buildings is going to be increased in any time section (Gehl, 1987).

Dr. Sajadzade in a paper "the role of attachment to place in giving identity to urban squares" mentioned general components regarding attachment to urban squares. These components and factors are shown in Table 1 (Sajadzade, 2013). 
Table 1. The effective factors on attachment in urban squares (Sajadzade, 2013)

\begin{tabular}{cll}
\hline & \multicolumn{1}{c}{$\begin{array}{c}\text { Components and } \\
\text { factors }\end{array}$} & Indices \\
\cline { 2 - 3 } $\begin{array}{c}\text { Attachment in Urban } \\
\text { Squares }\end{array}$ & Emotional & Comfort, memory, sociability feeling \\
\cline { 2 - 3 } & Performance & $\begin{array}{l}\text { Fulfilling daily needs, fulfilling environmental needs, spatial } \\
\text { possibility for pause }\end{array}$ \\
\cline { 2 - 3 } & Meaning & Giving identity to space, establishment situation, spatial quality,and \\
& architecture \\
\hline
\end{tabular}

To sum up, effective indices on presence and interaction of citizens in urban spaces are shown in Table 2.

Table 2. Effective indices on presence of citizens in urban spaces based on review of literature and theoretical basics (Authors)

\begin{tabular}{|c|c|}
\hline & $\begin{array}{l}\text { Effective indices on presence of citizens in urban spaces (based on review of } \\
\text { literature and theoretical foundations) }\end{array}$ \\
\hline $\begin{array}{c}\text { literature and theoretical } \\
\text { basics }\end{array}$ & $\begin{array}{l}\text { Motivation and free selection between the behaviors, adaptation with variety of } \\
\text { behaviours, opportunity of breaking some social borders, formation of social } \\
\text { interaction and contrast in space, leisure time in space, attracting various people } \\
\text { and groups/social security, access and continuity, comfort }\end{array}$ \\
\hline
\end{tabular}

\subsection{Public Spaces (Square) over Time}

The investigation of the historical trend of public spaces shows that first public spaces were monumental and public buildings as temple "Chatal Huke" in Anatoly and their background is older than the beginning of urbanization. In addition, in square as milestone of urban public spaces, from ancient Greece to the 20th century, the most important social events of European citizens have occurred.

This public space, which was called Agora in Greece and "Forum" in Rome, was the heart of European cities and social gatherings. But with the modern movement and functionalism, the separation of urban elements, zoning, and restricting city to four functions of residency, work, leisure and commute, urban spaces are gradually forgotten (Madanipour,2003).

The advent of modernism and its mechanized view toward city and its components, plus the development of "Form follows Function", public spaces of cities were considered as an indistinct whole. Here, the highest ventilation and light were considered as a conspicuous privilege to improve health conditions. Nevertheless, modernists did not pay enough attention or let us say ignored social and mental needs. Hence, the function of public space was not considered completely (Carmona et al, 2008).

Contemporary critics blame modernism for creating "dead public spaces", isolated and isolating spaces. Another criticism is regarding modern spaces as mostly the spaces for movement than staying. This isolation of modern human being in public domains is based on modern rationalization as Frankfort school theorists call it as instrumental rationality.

In Iran, scholars believe that the first Pahlavi period from Iran urbanization history regardless of its merits and demerits results was a transition era from old cities to new cities. In this era, urban planning changes were grown suddenly and actions taken in this period later became a model for urban policy of Iran. That is why this period is called as the beginning of modernity reflection in Iranian urbanization.

The change in first Pahlavi era was actually a reaction to unstable urban conditions and anomaly of public spaces of Qajar cities. The historical reports of this era, more specifically show the unsuitable conditions of Tehran city regarding public urban spaces and there are various reasons for that (Shabani, 2012).

One of the reasons is tribe structure of Qajar and influence of tribe view in this government. Thus, due to such influence, a city as Tehran was a temporary place; Great attentions were not given to its renovation and construction and new urban planning policies have not evolved with the changes of social life (Adl, 1996). 
Based on the catastrophic conditions of urban public spaces in Iran in Qajar era, one of the first and most necessary changes in urban policies was the formulation of rules, instructions, regulations to improve these spaces (Shabani, 2012). They are called development rules and construction of streets, rules of urban facades and improvement of urban space.

To coordinate streets with people houses and their traffic, Tehran municipality published public place construction rules in 1924. In the mentioned declaration issued by "Karim Bozarjomehri" in Municipality, in the first section, the people were asked to inform the municipality during the construction of new building to do the construction under the supervision of municipality's engineers. The municipality staffs were serious to construct the houses in accordance with the map, which provided by them. Another issue in the mentioned declaration is the law of facilitation of traffic and elimination of barriers from sidewalks and observing the rights of pedestrians (Iranian national documents organization, 1924).

On the other hand, west-based urban planning in Iran's cities showed itself in public urban spaces as the arrangement of new squares and intersections of streets. Europeans provided the map of many cities and it was based on capitalism thought. For example, the map of cities as Tehran and Hamedan were provided and implemented by French and German counselors in 1931 and 1937 (Habibi, 2007).

According to instructions of this period, only development of streets was considered from the view of municipality and ministry of interior and there was no urban planning regarding land use, utilities, infrastructures and urban equipment, organized relations in the division of urban spaces and generally a futuristic vision in the development plan. In addition, only by widening the streets and destroying precious and valuable lands, municipality instead of considering the qualitative improvements of the city, developed land speculation and brokerage (Shabani, 2012).

Unfortunately, many authorities and city managers had this taught and still some of them have. This problem shows the necessity of systematic and preventive monitoring With regard to the issues raised in this section, effective indices on presence or absence of citizens in urban spaces can be presented in Table 3 :

Table 3. Effective indices on presence of citizens in urban spaces based on historical trend of public spaces (Authors)

Effective indices on presence of citizens in urban spaces (based on historical trend of

Summary, historical public spaces)

trend of public spaces

Integration of urban texture and space/ health and environmental conditions, urban

policies, urban management, supervision and evaluation of urban management, urban rules, effects of international modern urbanization in non-European cities.

\section{Method}

To conduct research, analytical studies have been made and data collected by using library, fieldwork and World Wide Web network. The case study is Towhid square and the population is all citizens using this space. This study uses factor analysis and questionnaire. To determine sample size, Cochran's formula is used and the result is 149 . By reviewing literature, indices are extracted and after providing the questionnaire based on these indices, by Likert scale, we applied them to the case and completed the questionnaires.

For data analysis, SPSS 17 Software is used. Reliability and internal consistency of questions are evaluated by a pre-test. Cronbach's alpha is $91 \%$ showing the high reliability of the scale. In addition, the validity of questionnaire was approved by four experts and scholars.

\section{Case Study}

Nowadays we face increasing attention to personal vehicles, also increase of their production, reduce of efficiency of urban passages, and face with slow urban streets construction because of the rapid production of cars in our cities especially in the capital. One of the examples of this deprivation is in Towhid square and the surrounding area as by creating traffic in all paths leading to this square, disorder of vehicle interference in this square is problematic.

It seems that by establishing Towhid tunnel under this precinct, the surface does not need any planning and the travelers are forced to tolerate heavy traffic especially at the beginning and end of each day. The main goal of 
urban authorities of establishing Chamran highway, Towhid tunnel and Navab highway is rapid access of north to south of Tehran and vice versa (as it was mentioned in the master plan of Tehran city). After implementation of these big plans, the old urban textures were removed completely. In the next step, a great gap among the textures showed up, and finally it led into Navab highway.

After construction of Navab highway and achieving one of the main goal (rapid access of north to south), the immediate area of highway and its problems for residents related to the creation of indefensible spaces, lack of safety and amenity and so forth were neglected.

In recent years, an increase of traffic in Towhid square, plus before this square in Bagherkhan street intersection, Chamran highway and decrease of the speed of this main northern-southern artery forced authorities of city to rethink about this precinct. It was expected that authorities do not make the same mistake of Navab highway here But again without paying attention to the problems of residents of this precinct and just satisfying the need of people from other regions (their need to travel fast from this square), city authorities and the municipality of the region made a huge mistake.

The first action was blocking the relationship between Bagherkhan Street in two sides of Chamran highway, the first intersection in path was eliminated, it reduced the present traffic of Towhid square, and it led to the high balance of distribution of vehicle. By observing traffic in Towhid square and impossibility of blocking other paths leading to this square, the problem was eliminated by establishing Towhid tunnel and Chamran highway was connected rapidly to Navab highway. Thus, the problem of this highway and not the residents using it was eliminated and there was no need to improve the conditions of Towhid tunnel from urban authorities' view.

Another reason for the lack of attention to this square with its severe traffic is the location of this place among regions 2 and 6 of municipality of Tehran and consequently, it is quite fuzzy that who is responsible for this place. In figures 1-7, the condition of Towhid square can be seen. Towhid square is created by connection of a first degree urban arterial passage (Satarkhan st.) and Chamran highway. In addition, another passage leading to this square is second-degree arterial street (Nosrat Street) as continuing from another side of square (as one-way):

To be more precise, there are four passages entering square and the number of passages exiting are five. In addition, traffic load of each entrance passages to the square is high. Based on the foregoing, planning the paths without having interference and observing waiting time behind a red light is difficult. Hence, it needs practical and implementable solutions.

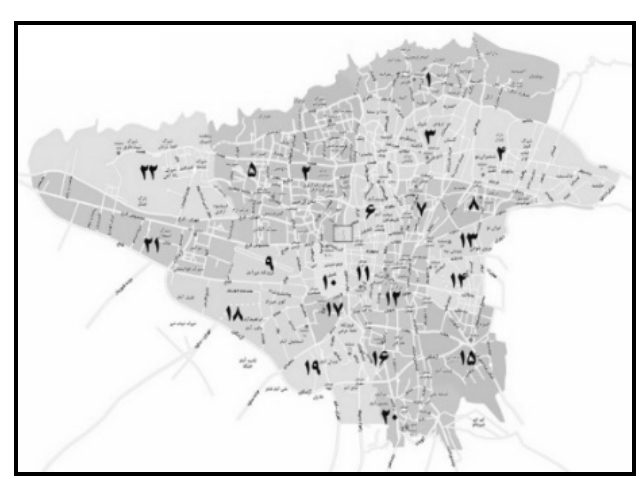

Figure 1. The study area in Tehran city

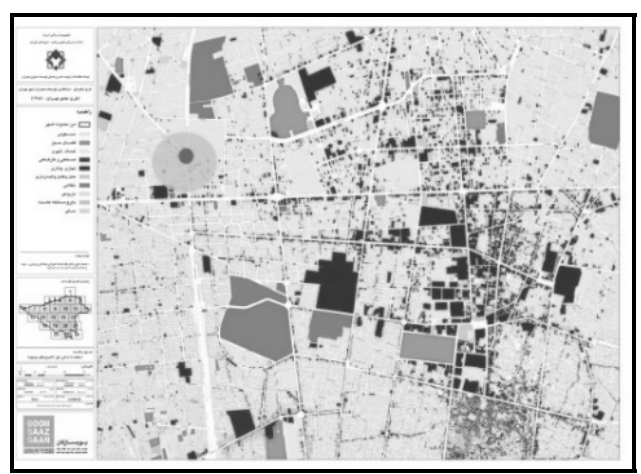

Figure 2. The study area (Ibid)

(The detailed plan of Tehran city) 


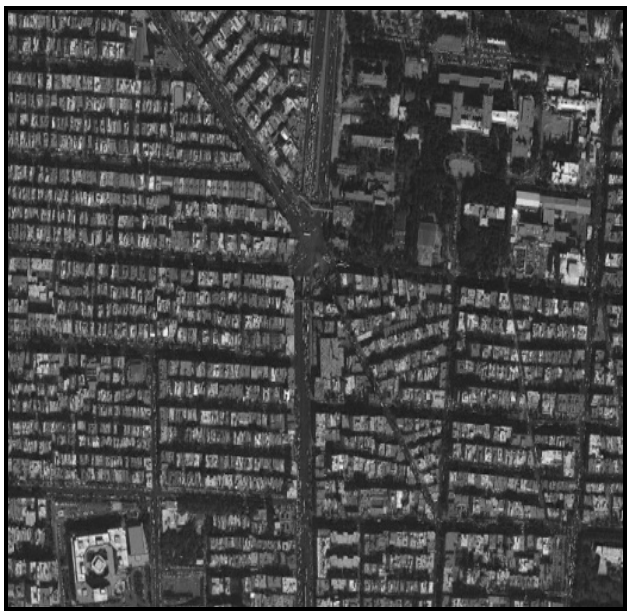

Figure 3. The study area (map.google.com)

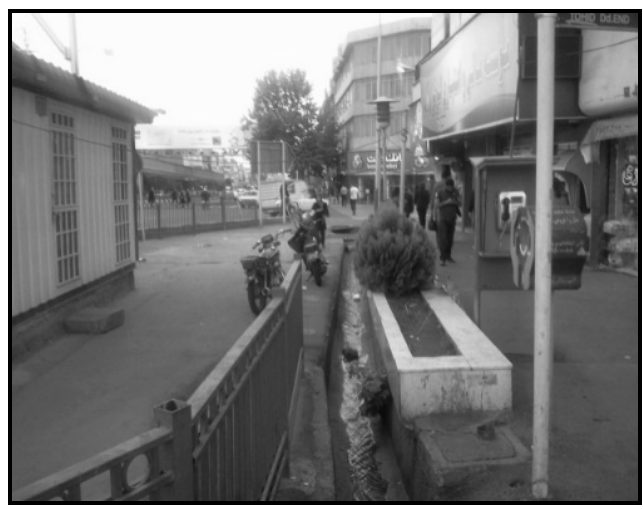

Figure 5. The study area (Authors)

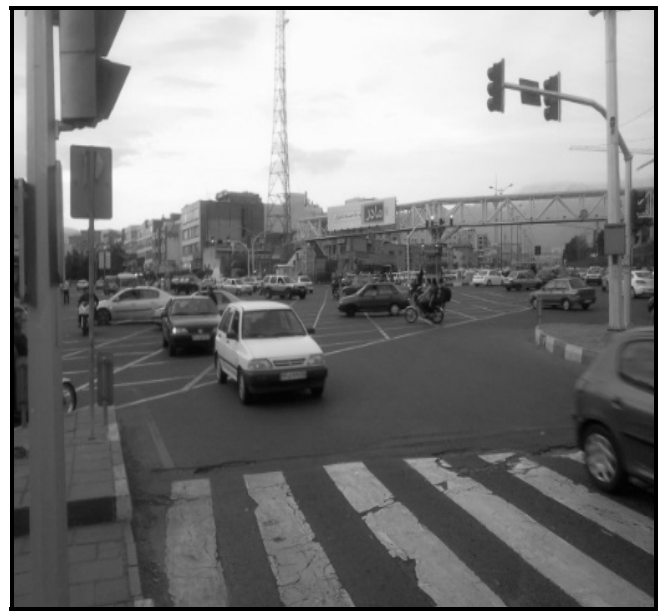

Figure 4. The study area (Authors)

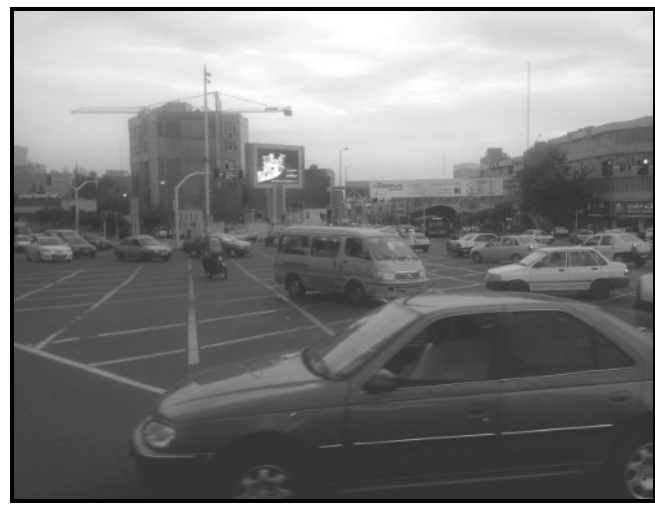

Figure 6. The study area (Authors)

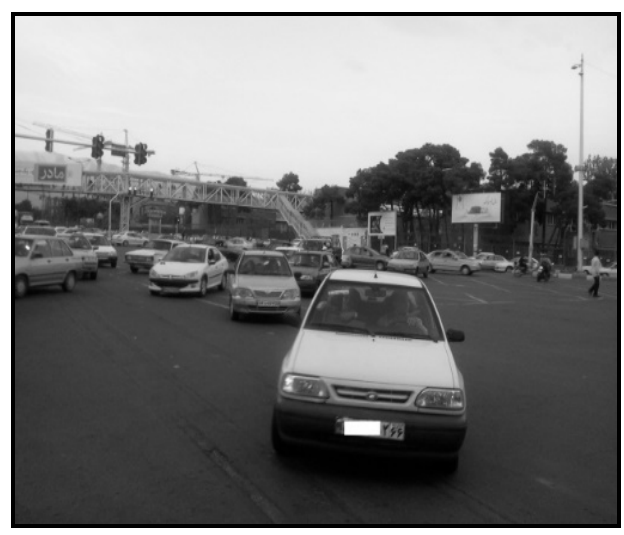

Figure 7. The study area (Authors)

As it was said, effective indices on presence or not -presence of citizens in urban spaces are presented in Table4 
Table 4. Effective indices on presence of citizens in urban spaces based on study area (Authors)

Effective indices on presence of citizens in urban spaces (based on studied area)

Summary, study area The effect of urban decision makers on urban space, lack of considering urban authorities to existing residents in urban texture around Towhid square, lack of determining to organizing existing spaces in urban regions and lack of the master plan of urban spaces in Tehran city/ traffic load prevents citizen's presence in square.

\section{Results}

Based on the conclusion in each of previous sections and on the other hand, by a combination of confirmatory factor analysis and explorative factor analysis, effective indices on the presence of citizens in urban space have been achieved. Overall, 25 indices are presented and table 5 indicates the indices name in SPSS software.

Table 5. Naming the indices in SPSS software (Authors)

\begin{tabular}{|c|c|}
\hline Indices & $\begin{array}{c}\text { Name in SPSS } \\
\text { software }\end{array}$ \\
\hline Activity and intimacy of square space & S.A \\
\hline Presence of various classes of people in space (many women, children and old people) & A.GH \\
\hline Scope and organizational integrity in urban management & GHAL \\
\hline Creating image and collective identity & $\mathrm{HOV}$ \\
\hline Introduction of citizens with urban space functions & A.SH \\
\hline Holding festivals and street show & JA \\
\hline Suitable access to urban space & DAS \\
\hline Flexible design (using at various times of day) & EN.FA \\
\hline Good safety and low traffic & IM \\
\hline Comfort, security & ASA \\
\hline Holding religious gathering & MAZ \\
\hline Low environmental pollution (noise, air and environmental pollution) & ALOD \\
\hline A space with dynamic social-cultural relations & RAVBE \\
\hline Information of urban authorities of function of urban spaces & $\mathrm{ASH} 2$ \\
\hline Attention of urban authorities to formation of social interactions in urban spaces & TAAMO \\
\hline Integrated urban management & MODI \\
\hline Space attraction & SBZ \\
\hline Happy activities can be performed & FAAL \\
\hline Possibility of creation and gathering of public buildings attracting population around square & JAZB \\
\hline Considering the residents in the area & SAK \\
\hline Holding gathering and demonstrations & PEY \\
\hline Having recreational-leisure performance & TAF \\
\hline With social, communication and cultural performance & EJ \\
\hline Having economic performance and presence of pedlars and retailers in urban spaces (square) & EGH \\
\hline $\begin{array}{l}\text { Suitable space for people presence (good urban furniture and access to services including public } \\
\text { transportation and shopping center) }\end{array}$ & MON \\
\hline
\end{tabular}


If the correlation between variables (indices) is less than 10-5, we encountered with severe correlation error between variables (Zebardast, 2014). In this paper, this error has not been made due to our determinant $(1.11 \mathrm{E}-005)$ which is correlation between indices. On the other hand, KMO value should be bigger and equal to 0.6 and Bartlett's test less than 0.05 (Ibid) in order to be sure that the number of samples is sufficient. As KMO is 0.785 and Bartlett's Test is less than 0.05, besides Cochran's formula, we can say the number of samples is selected as good.

The number of selected factors should be as a cumulative percentage of changes explains at least $60 \%$ of required changes (Ibid). Table 6 depicts the changes explaining each of the factors and we can observe cumulative percent of changes. As shown, four factors are selected and totally $63 \%$ of changes of citizens' presence in urban space are explained.

Table 6. The sum of explained changes by factors (Authors)

\begin{tabular}{|c|c|c|c|}
\hline \multirow{3}{*}{ Components } & \multicolumn{3}{|c|}{ Extraction Sums of Squared Loadings } \\
\hline & \multirow{2}{*}{ Total } & $\%$ & \multirow{2}{*}{ Cumulative $\%$} \\
\hline & & of Variance & \\
\hline 1 & 5.750 & 31.945 & 31.945 \\
\hline 2 & 2.817 & 15.648 & 47.593 \\
\hline 3 & 1.794 & 9.965 & 57.558 \\
\hline \multirow[t]{2}{*}{4} & 1.427 & 7.928 & 65.486 \\
\hline & \multicolumn{3}{|c|}{ Rotation Sums of Squared Loadings } \\
\hline \multirow[t]{2}{*}{ Components } & \multirow{2}{*}{ Total } & $\%$ & \multirow{2}{*}{ Cumulative $\%$} \\
\hline & & of Variance & \\
\hline 1 & 4.843 & 26.906 & 26.906 \\
\hline 2 & 2.488 & 13.823 & 40.730 \\
\hline 3 & 2.182 & 12.120 & 52.850 \\
\hline 4 & 1.962 & 10.902 & 63.751 \\
\hline
\end{tabular}

If a variable is close to two selected factors and it's some how fuzzy to decide which factor bestly explains the variable, Factor Rotation is required. Generally, there are two types of factor rotation which are 90-degree and oblique. In this analysis, 90-degree rotation and varimax sub-method are used and indices with the highest relation with factors (components) can be seen in subset of each of factors in Table 7. 
Table 7. Matrix of factors rotation (Authors)

\begin{tabular}{|c|c|c|c|c|}
\hline \multicolumn{5}{|c|}{ Rotated Component Matrix } \\
\hline & \multicolumn{4}{|c|}{ Component } \\
\hline & 1 & 2 & 3 & 4 \\
\hline RAVBE & .782 & & & \\
\hline ASA & .734 & & & \\
\hline A.SH & .603 & & & \\
\hline A.GH & .543 & & & \\
\hline S.A & .498 & & & \\
\hline $\mathrm{HOV}$ & .472 & & & \\
\hline IM & & .912 & & \\
\hline DAS & & .906 & & \\
\hline MON & & .885 & & \\
\hline SBZ & & .721 & & \\
\hline EN.FA & & .613 & & \\
\hline ALOD & & .502 & & \\
\hline SAK & & & .925 & \\
\hline MODI & & & .904 & \\
\hline ASH2 & & & .892 & \\
\hline JAZB & & & .871 & \\
\hline FAAL & & & .876 & \\
\hline TAAMO & & & .761 & \\
\hline GHAL & & & .689 & \\
\hline EGH & & & & .723 \\
\hline EJ & & & & .635 \\
\hline TAF & & & & .611 \\
\hline PEY & & & & .597 \\
\hline MAZ & & & & .576 \\
\hline JA & & & & .547 \\
\hline
\end{tabular}

\section{Discussion}

Finally, by analyses, four factors are extracted. Due to the indices under each factor and the conceptual framework which is derived from theoretical literature, each of the factors are named thoroughly. These influential factors on the presence of citizens in urban space (as described in table 8) are "social-cultural", "physical-environmental", "management" and "performance". Despite the hypothesis, the most important factor which led to the lack of presence (in contrast with passing) of citizens in Towhid square as an urban space is management factor.

The raised indices in theoretical literature are regarding "social-cultural", "physical-environmental" and "performance" and inattentive towards "management" factors on the presence of citizens in urban spaces. Based on factor loads value, we can say indices of "a space with dynamic social-cultural relations, "having good safety and low traffic", "good access to urban space", "considering residents of area", "integrated urban management" and "having economic performance" are the most important effective indices on presence of citizens in urban space. 
Table 8. Effective factors on presence of citizens in urban space (Authors)

\begin{tabular}{|c|c|}
\hline A space with dynamic social-cultural relations & \multirow{6}{*}{ Social-cultural } \\
\hline Comfort, security & \\
\hline Introduction of citizens with urban space functions & \\
\hline $\begin{array}{l}\text { Presence of various classes of people in space (many } \\
\text { women, children and old people) }\end{array}$ & \\
\hline Activity and intimacy of square space & \\
\hline Creating image and collective identity & \\
\hline Good safety and low traffic & \multirow{7}{*}{ Physical-Environmental } \\
\hline Suitable access to urban space & \\
\hline $\begin{array}{l}\text { Suitable space for people presence (good urban } \\
\text { furniture and access to services including public }\end{array}$ & \\
\hline transportation and shopping center) & \\
\hline Space attraction & \\
\hline Flexible design (using at various times of day) & \\
\hline $\begin{array}{l}\text { Low environmental pollution (noise, air and } \\
\text { environmental pollution) }\end{array}$ & \\
\hline Considering the residents in the area & \multirow{8}{*}{ Management } \\
\hline Integrated urban management & \\
\hline $\begin{array}{l}\text { Information of urban authorities of function of urban } \\
\text { spaces }\end{array}$ & \\
\hline Possibility of creation and gathering of public & \\
\hline buildings attracting population around square & \\
\hline Happy activities can be performed & \\
\hline $\begin{array}{l}\text { Attention of urban authorities to formation of social } \\
\text { interactions in urban spaces }\end{array}$ & \\
\hline $\begin{array}{l}\text { Scope and organizational integrity in urban } \\
\text { management }\end{array}$ & \\
\hline $\begin{array}{l}\text { Having economic performance and presence of } \\
\text { peddlers and retailers in urban spaces (square) }\end{array}$ & \multirow{6}{*}{ Performance } \\
\hline With social, communication and cultural performance & \\
\hline Having recreational-leisure performance & \\
\hline Holding gathering and demonstrations & \\
\hline Holding religious gathering & \\
\hline Holding festivals and street show & \\
\hline
\end{tabular}

\section{References}

Adl, S., \& Orkad, B. (1996). Tehran capital 20 years. Tehran. Technical and engineering consulting.

Behzadfar, M. (2013). Identification and evaluation of effective components in social interaction, development of citizens' relations in urban streets: Case study of Sanandaj. Baghnazar (17-28). NO. 25.

Carmona, M., Magalhaes, C., \& Hammond, L. (2008). Public Space. London \& New York: Rutledge.

Cullen, G. (1961). The concise Townscape. London: Architectural Press.

Gehl, J. (1987). Life between Building. Translated by J.Koch, NewYork. 
Goodmann, W. (1968). Principles and Practice of Urban Planning. Washington: International City Managers Association.

Habibi, M. (2007). From Shar to city. Tehran. Tehran University publications.

Holab, R. (2010). Yurgen Habermas. A criticism in the public field. Translated by Hossein Bashruye. Sixth edition. Tehran. Ney edition.

Iranian national documents organization. Declaration of Tehran Municipality about the construction of streets and shops. 1924. NO. 2-81004.

Karier, R. (1996). Urban space. Translated by Khosro Hasheminejad. First edition. Tehran:" Jihad Daneshgahi.

Khoshnevis, A. K. (2006). Iranian Utopia, Iranian urban space concept. Bagh Nazar. (101-118). No. 6.

Lynch, K. (1972). The Image of the City. Cambridge, Ma: The MIT Press.

Madanipour, A. (2003). Public and private spaces of the city. London: Routeledge.

Madanipour, A. (2008). The design of urban space: An approach to the social-spatial process. Translated by Farhad Mortezayi. Third edition. Tehran. Urban planning and Process Company.

Marcus, C. C., \& Francis,C. (1998). People places: Design guide lines for urban open space. New York: NY:Van Nostrand Reinhold.

Oldenburg, R. (1999). The Great Good Place: Cafes, Coffee shops, Community Center, Beauty parlors, General stores, Bars, Hangouts, and how they get through the day. Third Edition: Marlowe.336.

Pakzad, J. (2010). The thoughts in urbanization (Vol. 1-3). Tehran. Armanshahr publications.

Sajadzade, H. (2013). The role of attachment to place in giving identity to urban squares, case study: Aramgah square of Hamedan city. Baghnazar (79-88). NO. 25.

Sennette, R. (1974). The Fall of Public Man. New York:W W Norton \& company.

Shabani, E., \& Kamyab, J. (2012). Urban policy in the contemporary history of Iran with emphasis on public spaces of Tehran city. Baghnazar (83-92). No. 23.

Soltani, A. N., \& Ahmad, A. (2011). The analysis of the role of urban spaces in achieving sustainable development of cities. Explaining paradigm of relationship. Baghnazar (3-12). NO. 18.

The detailed plan of Tehran. 2006.

Whyte, W. H. (1980). The social life of small urban spaces. Tuxedo, Maryland:Printers II Inc.

Zebardast, E. (2014). The pamphlet of urban planning methods. Tehran University.

\section{Copyrights}

Copyright for this article is retained by the author(s), with first publication rights granted to the journal.

This is an open-access article distributed under the terms and conditions of the Creative Commons Attribution license (http://creativecommons.org/licenses/by/4.0/). 